\title{
MENINGKATKAN KETERAMPILAN PENULISAN PROPOSAL PENELITIAN TINDAKAN KELAS BAGI GURU SDN SAENAM
}

\author{
Oktovianus Mamoh \\ Program Studi Pendidikan Matematika, Fakultas Ilmu Pendidikan, \\ Universitas Timor, Indonesia \\ Pos-el: oktomamoh01@gmail.com
}

\begin{tabular}{|l|l|l|} 
Dikirim: 22 Juni 2018 & Direvisi: 27 Juli 2018 & Diterbitkan: 29 Agustus 2018
\end{tabular}

\begin{abstract}
Abstrak
Penelitian tindakan kelas (PTK) merupakan suatu kegiatan penelitian yang wajib dilakukan oleh para guru. PTK dikatakan wajib karena lewat penelitian ini, guru dapat meningkatkan profesionalnya dalam kegiatan pendidikan dan pengajaran. Tujuan PTK ini untuk dapat mengatasi masalah-masalah pembelajaran atau meningkatkan kegiatan pembelajaran. Kenyataan yang dihadapi oleh guru-guru SD di Kabupaten Timor Tengah Utara menunjukkan bahwa banyak guru SD yang belum dapat membuat proposal PTK. Hal ini berdasarkan pengamatan penulis dan wawancara dengan beberapa guru senior yang mengatakan bahwa hampir 90\% guru SD tidak mampu membuat proposal dan laporan PTK. Karena itu, penulis tergerak hati untuk melakukan pengabdian dosen dengan melakukan pelatihan penulisan proposal PTK bagi guru-guru SDN Saenam. Pengabdian ini telah dilakukan mulai dari tanggal 21 dan 27 Agustus 2017 di SDN Tubmanu, Desa Saenam, Kecamatan Miomaffo Barat. Metode yang digunakan adalah ceramah, diskusi dan praktek. Hasil pengabdian ini menggambarkan bahwa kegiatan pelatihan ini sangat penting bagi guru-guru SDN Tubmanu. Hal ini dapat dilihat dari 1) persentasi kehadiran mereka saat kegiatan berlangsung yang tidak pernah kurang dari 80\%; 2) keaktifan dan kreativitas mereka dalam mengikuti kegiatan pada setiap langkah-langkah PTK; 3) motivasi mereka untuk meningkatkan pengetahuan dan keterampilan dalam mengelolah kelas untuk dapat meningkatkan prestasi belajar siswa. Hal ini ditandai dengan antusias para guru dalam menemukan masalah-masalah yang terjadi di kelas dan mencari solusi/penyelesaian yang tepat; 4) meningkatkan kemampuan menulis terutama proposal dan laporan hasil PTK.
\end{abstract}

Kata kunci: pelatihan, keterampilan, penelitian tindakan, kelas 


\begin{abstract}
Classroom action research (CAR) is a research activity that must be carried out by the teacher. CAR is a important thing for teachers because through this research, teachers can improve their professionalism in education and teaching activities. The purpose of this CAR is to overcome learning problems or improve learning activities. The reality faced by elementary teachers in Timor Tengah Utara District shows that many elementary teachers have not been able to make PTK proposals. This is based on the author's observations and interviews with several senior teachers who said that almost $90 \%$ of elementary school teachers were unable to make PTK proposals and reports. Therefore, the writer want to conduct PTK proposal writing training for the teachers of Saenam SDN. This activity has been carried out on August 21 and 272017 at Tubmanu Elementary School, Saenam Village, West Miomaffo District. The method used are lectures, discussions and practices. The results show that this training activity is very important for the teachers of Tubmanu Elementary School. This can be seen from 1) the percentage of their attendance during activities that have never been less than 80\%; 2) student's activeness and creativity in activities of PTK; 3) students's motivation to improve their knowledge and skills in managing classes to improve their learning achievement. This is marked by enthusiastic teachers in finding problems that occur in class and finding the right solutions; and 4) improve writing skills, especially proposals and reports on PTK results.
\end{abstract}

Key words: classroom, action, training, skills, research.

\title{
PENDAHULUAN
}

Pendidikan yang berkualitas merupakan dambaan semua level pendidikan baik dari tingkat sekolah dasar, menengah maupun perguruan tinggi. Salah satu upaya peningkatan kualitas pendidikan di sekolah dapat ditempuh melalui peningkatan kinerja guru menjadi guru yang profesional. Profesional adalah pekerjaan atau kegiatan yang dilakukan oleh seseorang dan menjadi sumber penghasilan kehidupan yang memerlukan keahlian, kemahiran atau kecakapan yang memenuhi standar mutu atau norma tertentu serta memerlukan pendidikan profesi (Kunandar, 2007:45). 
Suryasubrata (1997:4-5) menyatakan bahwa kemampuan profesional guru dapat diwujudkan dalam penguasaan sepuluh kompetensi guru, yang meliputi: (a) Menguasai bahan, (b) Mengelola program belajar mengajar, (c) Mengelola kelas, (d) Penggunaan media atau sumber, (e) Menguasai landasan-landasan pendidikan. (f) Mengelola interaksi-interaksi belajar mengajar. (g) Menilai prestasi siswa untuk kepentingan pelajaran. (h) Mengenal fungsi layanan bimbingan dan konseling di sekolah (i) Mengenal dan menyelenggarakan administrasi sekolah. (j) Memahami prinsip-prinsip dan menafsirkan hasil penelitian pendidikan guna keperluan pengajaran.

Namun dalam perkembangan zaman guru yang profesional tidak hanya sebatas memahami prinsip-prinsip dan menafsirkan hasil penelitian pendidikan guna keperluan pengajaran tetapi dituntut untuk menjadi pelaku utama dalam penelitian. Guru dituntut untuk melakukan penelitan untuk menunjang profesionalnya sebagai seorang guru. Penelitian pendidikan yang dilakukan oleh seorang guru dimaksudkan untuk mengatasi masalah-masalah yang dihadapi di dalam kelas. Solusi untuk mengatasi masalah pembelajaran yang dihadapi saat menjalankan tugasnya dapat dilakukan melalui penelitian tindakan kelas yang dilakukan secara kolaboratif. Dengan adanya Penelitian Tindakan Kelas (PTK) masalah-masalah pendidikan dan pembelajaran di kelas dapat dikaji, diidentifikasi, diperbaiki, dan dituntaskan bahkan ditingkatkan. Dengan demikian maka proses pendidikan dan pembelajaran yang inovatif dan target untuk memperoleh hasil belajar yang lebih baik, dapat tercapai.

Jika tuntutan guru profesional demikian, maka setiap Guru diharapkan dapat melakukan penelitian tindakan kelas. Namun kenyataannya bahwa masih banyak guru termasuk guru-guru pada SDN Saenam tidak/belum mau menulis, bahkan ada yang tidak mampu menulis proposal penelitian. Dalam wawancara dengan kepala sekolah SDN Saenam, mengatakan bahwa hampir $90 \%$ guru tidak bisa membuat proposal penelitian. Menurut Beliau, hal yang paling sulit dilakukan adalah bagaimana mengidentifikasi masalah dan memulai merangkai kalimat-kalimat itu untuk menjadi sebuah tulisan. Pernyataan ini sesuai dengan hasil penelitian Nitiasih (2009) yang menyatakan bahwa $85 \%$ guru dan 90\% kepala sekolah tidak mampu menemukan masalah yang dapat dijadikan penelitian tindakan kelas untuk guru-guru dan penelitian tindakan sekolah untuk Kepala Sekolah dan Pengawas.

Pemerintah dan pihak sekolah sering mengirimkan guru-guru untuk mengikuti pelatihan dan seminar atau jenis kegiatan sejenis lainnya, tentang penelitian tindakan kelas sebagai solusi dari masalah di atas, namun kenyatannya masih banyak guru-guru 
yang belum mampu menulis karya tulis ilmiah termasuk proposal penelitian tindakan kelas. Hal ini dikarenakan model pelatihan yang diikuti lebih banyak memfokuskan pada kajian teoritis dan kurang penyajian contoh-contoh kongkret sehingga ketika selesai mengikuti pelatihan mereka tidak memahami dengan baik konsep yang telah diajarkan dan ketika kembali ke sekolah mereka kembali tidak mampu melakukan penelitian.

Penelitian tindakan kelas merupakan salah satu tawaran penelitian yang cocok untuk guru-guru. Karena lewat penelitian ini, seorang guru dapat mengatasi persoalan yang terjadi di kelas, atau masalah-masalah yang dihadapi siswanya pada kelas yang diasuh. Sejalan itu, Sukarnyana (2006:9) mengatakan PTK merupakan salah satu upaya guru atau praktisi dalam bentuk berbagai kegiatan yang dilakukan untuk memperbaiki keadaan yang tidak/kurang memuaskan dan atau meningkatkan mutu pembelajaran di kelas. Karena itu, PTK merupakan kegiatan yang langsung berhubungan dengan tugas guru di lapangan.

Sehubungan dengan pendapat di atas, Kemmis dan Car (dalam Sukarnyana 2006) menyatakan bahwa penelitian tindakan merupakan suatu bentuk penelitian yang bersifat reflektif yang dilakukan oleh pelaku dalam masyarakat sosial dan bertujuan untuk memperbaiki pekerjaannya, memahami pekerjaan ini serta situasi dimana pekerjaan ini dilakukan. Dalam konsep ini, kedua pakar tersebut di atas memaasukan bidang pendidikan di dalamnya. Ini berarti guru diharapkan ikut terlibat dalam pelaksanaan suatu tindakan kelas. Kedua pakar ini juga mengatkan bahwa, situasi tidak akan berubah cepat sesuai apa yang dikatakan oleh para guru. Perubahan merupakan suatu proses yang memerlukan waktu dan kesabaran, kalau perubahan itu menyangkut sikap. Karena itu, peneliti diharapkan untuk belajar banyak tentang proses perubahan itu sendiri, yaitu bahwa mereka memerlukan orang lain yang harus dilibatkan dalam proses belajar mengajar.

Kurt Lewin (dalam Sukarnyana, 2006:10) orang yang mempopulerkan PTK mengatakan bahwa cara terbaik untuk memajukan orang adalah dengan melibatkan mereka dalam penelitian yang ada dalam kehidupan mereka. Pernyataan di atas menekankan pentingnya kolaborasi dan partisipasi yang bersifat demokratis. Selanjutnya, PTK digambarkan sebagai suatu lingkaran atau rangkaian langkah-langkah (a spiral of step) yang satu dengan yang lain saling berhubungan. Langkah-langkah PTK ini terdiri dari perencanaan (planing), tindakan (acting), pengamatan (observation), dan refleksi (reflection). 


\section{METODE}

Kegiatan pelatihan penulisan proposal PTK ini dilaksanakan pada tanggal 21 dan 27 Agustus 2017. Peserta pelatihan adalah guru-guru SDN Saenam. Pelaksanaan kegiataan pelatihan ini menggunakan metode ceramah, diskusi dan praktek. Metode ceramah digunakan untuk menjelaskan pengertian PTK, karakteristik dan langkahlangkah penyusunan proposal PTK. Sedangkan diskusi dipakai untuk membagikan pengalaman, kesulitan atau hal-hal lain yang berhubungan dengan penulisan proposal PTK. Dan praktek dipakai untuk membimbing peserta untuk berlatih menulis.

\section{HASIL DAN PEMBAHASAN}

SDN Saenam memiliki nama lembaga sebenarnya SDN Tubmanu yang terletak di desa Saenam. Jarak Desa Saenam dari kota Kefamenanu kurang lebih $40 \mathrm{~km}$. Pada tahun ajaran 2017/2018 SDN Tubmanu memiliki 9 guru dimana 6 orang staf guru merupakan guru kelas, sedangkan 3 orang lainnya lainnya merupakan guru mata pelajaran yakni guru agama 2 orang dan 1 guru bahasa Inggris. Jabatan fungsional atau pangkat dan golongan yang dimiliki oleh guru-guru tersebut, dapat diuraikan sebagai berikut: a. Untuk golongan yang paling tinggi IVA sebanyak 2 orang. b. Golongan IIIC sebanyak 3 orang. c. Golongan IIIB sebanyak 2 orang. d. Golongan IIla 1 oranag dan golongan II sebanyak 1 orang. Saat survei lokasi, para guru-guru mengatakan bahwa mereka sangat membutuhkan hasil karya tulis ilmiah untuk kenaikan pangkat dan urusan-uusan lainnya. Karena itu, kehadiran penulis untuk membawakan materi pelatihan karya tulis ilmiah khusus pelatihan penulisan proposal PTK merupakan salah satu langkah yang tepat untuk menjawabi tuntutan tersebut.

Tatap muka pertama dalam kegiatan pelatihan ini dilakukan pada tanggal 21 Agustus 2017 jam 8 pagi dengan jumlah guru yang hadir sebanyak 6 orang. Pada kegiatan yang pertama ini, saya memberikan ceramah dan diskusi tentang bagaimana menyusun proposal PTK, dengan langkah-langkah pelatihan sebagai berikut:

a). Menyampaikan skenario pelatihan

Hal-hal yang akan dilakukan dalam kegiatan pelatihan ini disertai dengan waktu yang tentukan disampaikan dalam skenario ini. Kesempatan ini juga penulis membagi kegiatan tersebut menjadi 3 bagian yaitu kegiatan pendahuluan yang berisi tentang topik yang akan dibahas, kompetensi, indikator pencapaian kompetensi, kegiatan pelatihan yang akan dilakukan. Kegiatan inti, memberikan Ceramah tentang kerangkah 
PTK, Siklus PTK dan sistematika penulisan PTK. Selanjutnya, kegiatan diskusi dan tanya jawab mengenai kerangkah PTK, siklus PTK dan sistematika penulisan proposal PTK.

\section{b). Kerangkah PTK}

Pada langkah ini saya menyampaikan kerangkah penulisan proposal PTK, dimana guru harus memperhatikan kondisi awal munculnya masalah yang terjadi dalam kegiatan pembelajaran, baik dari awal (pembuatan perangkat pembelajaran, pelaksanaan pembelajaran maupun diakhir. Kebanyakan masalah yang terjadi, kompetensi siswa belum memenuhi. Jika persiapan/perencanaan pembelajarannya bagus, maka coba perhatikan penerapan metode, atau strategi pembelajaran. Ketika sudah menemukan akar masalah, maka coba untuk membuat perencanaan perbaikan untuk meningkatkan hasil belajar siswa. Perencanaan perbaikan ini dengan menerapkan strategi yang baru. Kemudian pelaksanaannya dalam sklus-siklus. Dimana setiap siklus terdiri dari 4 tahapan yaitu perencanaan, pelaksanaan tindakan, observasi dan refleksi. Di tahap tersakhir setiap siklus ini, kita merefleksikan apakah hasil yang kita lakukan ini sudah mencapai target atau belum. Jika belum maka kita perlu menambah satu siklus lagi dengan cara merefleksikan masalah apa yang terjadi disiklus sebelumnya dan melakukan perencanaan baru untuk melakukan perbaikan pada siklus berikutnya.

\section{c). Siklus PTK}

Pada poin kerangkah PTK telah disinggung bahwa setiap siklus PTK harus memuat 4 tahapan yang harus dilalui yang meliputi perencanaan, pelaksanaan, observasi/pengamatan dan refleksi. Kemudian maju ke siklus berikut dengan langkahlangkah yang sama.

\section{d). Sistematika penulisan Proposal PTK}

Secara umum sistematika penulisan proposal terdiri dari tiga bagian pokok yaitu: 1) bagian awal; terdiri dari halaman judul, halaman persetujuan, kata pengantar, daftar isi, daftar tabel, daftar lampiran, 2) bagian isi terdiri dari : pendahuluan yang berisi latar belakang, perumusan masalah, tujuan penelitian, manfaat, batasan istilah, landasan teori, dan hipotesis tindakan, metode penelitian., 3) bagian penunjang berisi tentang daftar pustaka dan lampiran-lampiran.

Tatap muka kedua dilakukan pada tanggal 27 Agustus 2017. Hal yang dilakukan pada tahap ini adalah mendampingi guru menyusun latar belakang, perumusan 
masalah, tujuan penelitian, manfaat penelitian, batasan istilah. Kemudian kami mencoba menyusun proposal ini dengan latar belakang ilmu masing-masing. Kendalakendala yang dihadapi saat melakukan pelatihan ini adalah kurangnya koordinasi dengan dinas pendidikan sehingga guru-guru merasa bahwa kegiatan pelatihan ini kurang penting. Padahal harusnya kegiatan ini sangat bermanfaat bagi mereka. Kendala lain yang dihadapi adalah belum terbiasanya para guru membuat tulisan ilmiah apalagi membuat proposal penelitian. Hal ini yang membuat guru-guru berat mengikuti kegiatan tersebut terlebih menyusun proposal PTK. Namun berkat semangat juang untuk memperoleh ilmu dan keterampilan yang lebih ditambah dengan pentingnya pelatihan ini maka mereka mengikuti setiap proses sampai selesai.

\section{SIMPULAN}

Dalam kegiatan pelatihan penulisan proposal PTK hendaknya diperhatikan langkah-langkah penyusunan proposal PTK yang terdiri dari identifikasi masalah, menerapkan metode atau strategi yang tepat untuk mengatasi masalah yang sedang dihadapi, menyusun langkah-langkah pelaksanaan dalam bentuk siklus-siklus, kemudian tahu membuat refleksi/perbaikan. Penulisan proposal PTK sendiri memiliki beberapa bagian yaitu bagian awal yang terdiri dari halaman judul, persetujuan, kata pengantar, daftar isi, daftar tabel, daftar gambar dan daftar lampiran. Sedangkan bagian isi menyangkut pendahuluan, kajian teori dan metode penelitian. Selanjutnya bagian penutup menyangkut datar pustaka dan lampiran-lampiran.

Akhir dari pengabdian ini, penulis yang adalah pengabdi sadar bahwa masih banyak terdapat kekurangan dalam menyelesaikan kegiatan pengabdian ini. Karena itu, pengabdi akan selalu melakukan refleksi demi perbaikan dan peningkatan mutu pengabdian dan hasil nanti.

\section{UCAPAN TERIMA KASIH}

Kami menyampaikan terima kasih kepada LPPM universitas Timor yang telah mendanai dan mendukung kegiatan pengabdian ini. 


\section{DAFTAR PUSTAKA}

Arikunto S, Suhardjono, dan Supardi. (2008). Penelitian Tindakan Kelas. Jakarta: Bumi Aksara.

Fx. Soedarsono. 2001. Aplikasi Penelitian Tindakan Kelas. Direktorat Jenderal Pendidikan Tinggi Departemen Pendidikan Nasional, Jakarta.

Kunandar. 2011. Guru Profesional, Implementasi KTSP dan Sukses Dalam Sertifikasi Guru. Jakarta: Rajawali Pers.

Nitiasih, Putu Kerti, 2010. Model Workshop Penelitian Tindakan Kelas Reflektif Berbasis Kompetensi (PTK-RBK) Untuk Meningkatkan Profesionalisme Guru di Provinsi Bali. Hasil Penelitian yang tidak dipublikasikan.

Rindjin, Sarna, Padmadewi. 2006. Diagnosis Masalah Pembelajaran (Makalah disampaikan dalam Focused Group Discussion antar Guru-Guru SD, SMP se Kabupaten Banjar tanggal 21 Oktober 2006.

Suryasubrata, 1997. Proses Belajar Mengajar di Sekolah. Jakarta: Rineka Cipta.

Sukarnyana. I.W. 2006. Penelitian Tindakan Kelas. Malang: Penerbit Universitas Negeri Malang

T.Raka Joni.1998. Penelitian Tindakan Kelas: Beberapa Permasalahannya. Jakarta: PCPPGSM Dirjen Dikti.

Wina Sanjaya. (2010). Penelitian Tindakan Kelas. Jakarta: Kencana. 